\title{
Neutrophil Elastase and Cathepsin G Stimulate Secretion from Cultured Bovine Airway Gland Serous Cells
}

\author{
Christian P. Sommerhoff, ${ }^{\star}$ Jay A. Nadel, ${ }^{\star * 5}$ Carol B. Basbaum, ${ }^{\star \|}$ and George H. Caughey* \\ *Cardiovascular Research Institute and Departments of ${ }^{\ddagger}$ Medicine, ${ }^{\S}$ Physiology and "Anatomy, \\ University of California, San Francisco, California 94143-0130
}

\begin{abstract}
To investigate the hypothesis that neutrophil proteases stimulate airway gland secretion, we studied the effect of human cathepsin $\mathbf{G}$ and elastase on secretion of ${ }^{35} \mathrm{~S}$-labeled macromolecules from cultured bovine airway gland serous cells. Both proteases stimulated secretion in a concentration-dependent fashion with a threshold of $\geq 10^{-10} \mathrm{M}$. Elastase was more potent than cathepsin $G$, causing a maximal secretory response of $1,810 \pm 60 \%$ over baseline at $10^{-8} \mathrm{M}$. The maximal response to cathepsin $G\left(1,810 \pm 70 \%\right.$ over baseline at $\left.10^{-7} \mathrm{M}\right)$ was similar to the maximal response to elastase. These responses were $>$ 10-fold larger than the response to other agonists such as histamine. Protease-induced secretion was noncytotoxic and required catalytically active enzymes. The predominant sulfated macromolecule released by proteases was chondroitin sulfate proteoglycan. Immunocytochemical staining demonstrated chondroitin sulfate in cytoplasmic granules and decreased granular staining after stimulation of cells with elastase. The neutrophil proteases also degraded the proteoglycan released from serous cells. Cathepsin $G$ and elastase in supernatant obtained by degranulation of human peripheral neutrophils also caused a secretory response. Thus, neutrophil proteases stimulate airway gland serous cell secretion of chondroitin sulfate proteoglycan and degrade the secreted product. These findings suggest a potential role for neutrophil proteases in the pathogenesis of increased and abnormal submucosal gland secretions in diseases associated with inflammation and neutrophil infiltration of the airways. (J. Clin. Invest. 1990. 85:682-689.) serine proteases $\bullet$ exocytosis $\bullet$ chondroitin sulfate proteoglycan
\end{abstract}

\section{Introduction}

Neutrophils are thought to play a major role in generating the pathologic manifestations of airway inflammation, whose features include increased and abnormal airway secretions. Airway neutrophils are found in higher number in the airways of

This work appeared previously in abstract form (1989. FASEB [Fed. Am. Soc. Exp. Biol.] J. 3:A534. [Abstr.]).

Dr. Sommerhoff's current address is Abteilung für Klinische Chemie und Klinische Biochemie in der Chirurgischen Klinik Innenstadt der Universität, Nussbaumstrasse 20, D-8000 Munich 2, FRG.

Address correspondence to Dr. George H. Caughey, Cardiovascular Research Institute, Box 0310, University of California, San Francisco, CA 94143-0130.

Received for publication 14 July 1989 and in revised form 18 October 1989.

J. Clin. Invest.

(C) The American Society for Clinical Investigation, Inc.

0021-9738/90/03/0682/08 $\$ 2.00$

Volume 85, March 1990, 682-689 cigarette smokers than in nonsmokers $(1,2)$, and are greatly increased in the purulent respiratory tract secretions of patients with chronic bronchitis and cystic fibrosis. Environmental stimuli such as ozone and sulfur dioxide, which cause an influx of neutrophils into the airways (3-6) can also be associated with bronchitis and hypersecretion $(5,7)$. Neutrophils are a source of a variety of potentially important mediators of inflammation, including neutral proteases. Prominent among these are the lysosomal proteases cathepsin $G$ and elastase, which are released from neutrophils during phagocytosis and cell death $(8,9)$. Levels of catalytically active cathepsin $\mathrm{G}$ and elastase are negligible in normal airway secretions, but are greatly increased in purulent airway secretions. In patients with cystic fibrosis, for example, concentrations of neutrophil elastase in sputum may exceed $100 \mu \mathrm{g} / \mathrm{ml}\left(3.3 \times 10^{-6} \mathrm{M}\right)(10$, 11). Free neutrophil protease activity may also be present in the airways of cigarette smokers and individuals with bronchitis (12-16). Neutrophils also infiltrate tissue lying beneath the airway mucosal surface in these conditions, where they may interact with subepithelial structures involved in secretion, e.g., submucosal glands. Inflammation of submucosal glands has been associated with continuing mucus hypersecretion in ex-smokers (17).

Several lines of evidence arising from the study of surface airway epithelial cells suggest a connection between the release of neutrophil proteases and pathologic alterations in secretion. For example, neutrophil elastase causes goblet cell discharge in hamsters in vivo (18) and releases cell surface glycoconjugates from tracheal surface epithelial cells of dogs and guinea pigs in vitro (19-21). However, in humans the greatest contribution to airway secretions is thought to originate from submucosal gland secretory cells whose volume is $\mathbf{4 0}$ times that of goblet cells in normal airways (22). In chronic bronchitis and cystic fibrosis, the predominance of submucosal gland secretory cells is even more striking due to the gland hypertrophy and hyperplasia associated with these conditions $(22,23)$. However, the effect of neutrophil proteases on airway submucosal gland secretion has not been examined. Therefore, the current study was designed to examine the hypothesis that neutrophil proteases stimulate secretion of airway submucosal glands. The incentive for these studies was our previous finding that chymase, a chymotrypsin-like mast cell protease closely related to neutrophil cathepsin $G$, degranulates tracheal gland serous cells (24). Our studies used a cultured line of bovine tracheal gland serous cells that maintains characteristics of differentiated serous cells (25-27). The current findings demonstrate that both neutrophil cathepsin $\mathrm{G}$ and elastase are potent noncytotoxic serous cell secretagogues that degrade the chondroitin sulfate proteoglycan whose secretion they stimulate.

\section{Methods}

Materials. Media, FCS, and antibiotics were obtained from the Cell Culture Facility of the University of California, San Francisco. Car- 
rier-free $\mathrm{Na}_{2}{ }^{35} \mathrm{SO}_{4}$ (sp act, $43 \mathrm{Ci} / \mathrm{mg}$ ) was purchased from ICN Radiochemicals, Inc. (Irvine, CA). Human neutrophil elastase and cathepsin $\mathrm{G}$ isolated from human purulent sputum were purchased from Elastin Products (Pacific, MO). Soybean trypsin inhibitor, chymostatin, $\alpha_{1-}$ proteinase inhibitor, PMSF, histamine, 3-isobutyl-1-methylxanthine, succinyl-Ala-Ala-Pro-Val-4-nitroanilide, and the MAb CS-56 were purchased from Sigma Chemical Co. (St. Louis, MO), and cytochalasin B and FMLP from Calbiochem-Behring Corp. (San Diego, CA). Chondroitinase $\mathrm{ABC}$ and $\mathrm{AC}$ were obtained from ICN Radiochemicals (Irvine, CA). $\mathrm{N}$-Methoxysuccinyl-Ala-Ala-Pro-Val-chloromethylketone was obtained from Enzyme Systems Products (Livermore, CA), and succinyl-Ala-Ala-Pro-Phe-4-nitroanilide from Vega Biotechnologies, Inc. (Tucson, AZ).

Culture of bovine tracheal gland serous cells. A line of bovine tracheal gland serous cells was cultured as described previously $(24,25)$. Cells were studied between passages 10 and 25 . Cells were seeded at a density of $2 \times 10^{4}$ cells $/ \mathrm{cm}^{2}$ on tissue-culture plastic coated with human placental collagen $\left(15 \mu \mathrm{g} / \mathrm{cm}^{2}\right)(28)$ in medium containing $40 \%$ Dulbecco's modified Eagles' H21 medium, 40\% Ham's F12 medium, $20 \% \mathrm{FCS}$, and $50 \mu \mathrm{g} / \mathrm{ml}$ gentamicin. Flasks were maintained at $37^{\circ} \mathrm{C}$ in $5 \% \mathrm{CO}_{2} / 95 \%$ air. The medium was changed every $3 \mathrm{~d}$.

Release of ${ }^{35} \mathrm{~S}$-labeled macromolecules. On day 9 confluent monolayers were incubated with medium containing $\mathrm{Na}_{2}{ }^{35} \mathrm{SO}_{4}(7.5 \mu \mathrm{Ci} / \mathrm{ml})$. After $24 \mathrm{~h}$ the medium containing the radiolabel was removed and the cells were washed three times with PBS. Serum-free medium (50\% Dulbecco's modified Eagles' H21 medium, 50\% Ham's F12 medium) containing $100 \mu \mathrm{g} / \mathrm{ml}$ streptomycin and $100 \mathrm{U} / \mathrm{ml}$ penicillin was then added, and it was renewed every $30 \mathrm{~min}$ for $210 \mathrm{~min}$. At $210 \mathrm{~min}$ medium containing the agonists was added to the cells. Protease inhibitors were preincubated with the proteases for $5 \mathrm{~min}$ before addition to the cells. After $30 \mathrm{~min}$ the medium was collected again and the culture flasks were examined using a phase microscope (ITM-2; Olympus Corporation of America, New Hyde Park, NY) to verify the integrity of the cell monolayer.

The spent medium from the 180 - to $210-\mathrm{min}$ and the 210 - to 240-min incubation periods was dialyzed (Spectrapor tubing molecular mass cutoff, 12,000-14,000 D) against distilled water containing 10 $\mathrm{mg} /$ liter sodium azide to remove unincorporated ${ }^{35} \mathrm{SO}_{4}^{2-}$. Nondialyzable ${ }^{35}$ S-labeled macromolecules were counted after addition of scintillation fluid (Hydrofluor; National Diagnostics, Inc., Somerville, NJ) by scintillation spectroscopy to an accuracy of $2 \%$ (beta counter model LS7500; Beckman Instruments, Inc., Palo Alto, CA).

Secretion is expressed as percent increase of release of ${ }^{35} \mathrm{~S}$-labeled macromolecules during incubation with the agonists over the release during the immediately preceding time period and was corrected for the declining baseline (determined in controls incubated with medium alone).

Analysis of cellular and secreted radiolabeled macromolecules. Serous cells were cultured and labeled, and the label was chased as described above. After incubation with proteases or medium alone, the spent medium was collected and cooled rapidly. Cell monolayers were washed three times with PBS and dissolved in $4 \mathrm{M}$ guanidine chloride, 0.5\% 3-[(3-cholamidopropyl)dimethylammonio]-1-propane sulfonate (CHAPS) $^{1}$, and $0.1 \mathrm{M}$ sodium acetate (pH 6.0). Soybean trypsin inhibitor (final concentration, $1 \mathrm{mg} / \mathrm{ml}$ ) and $\alpha_{1}$-proteinase inhibitor (final concentration, $0.1 \mathrm{mg} / \mathrm{ml}$ ) were added to all samples to minimize possible degradation of macromolecules by remaining proteases. The samples were dialyzed, lyophilized, and stored at $-20^{\circ} \mathrm{C}$.

Gel filtration chromatography was performed on a Superose 6 column (Pharmacia Fine Chemicals, Piscataway, NJ). Samples were eluted under dissociative conditions (4 M guanidine chloride, $0.5 \%$ CHAPS, $0.1 \mathrm{M}$ sodium acetate; $\mathrm{pH}$ 6.0) to dissociate ionic bonds and disaggregate proteoglycans (29). $0.5-\mathrm{ml}$ fractions were collected, and aliquots were counted for radioactivity after addition of scintillant.

1. Abbreviations used in this paper: CHAPS, 3-[(3-cholamidopropyl) dimethylammonio]-1-propanesulfonate; $\mathrm{LDH}$, lactic acid dehydrogenase.
To identify the nature of the radiolabeled glycoconjugates, the fractions containing radiolabeled material were pooled, dialyzed, and lyophilized again. Aliquots were subjected to gel filtration chromatography after digestion with chondroitinase $\mathrm{ABC}$ or chondroitinase $\mathrm{AC}$ $(0.5 \mathrm{U} / \mathrm{ml})$ or after incubation with the buffer $(0.1 \mathrm{M}$ Tris-acetate, $\mathrm{pH}$ 7.3) alone at $37^{\circ} \mathrm{C}$ for $18 \mathrm{~h}$.

Analysis of cytotoxicity. Possible cytotoxicity of neutrophil cathep$\sin \mathrm{G}$ and elastase (each $10^{-7} \mathrm{M}$ ) was determined by measurements of the release of lactic acid dehydrogenase (LDH) and by vital dye exclusion. Serous cells were seeded in human placental collagen-coated 6-well tissue culture plates $\left(10 \mathrm{~cm}^{2}\right.$ surface area/well) and maintained as described above. On day 10 the cells were washed three times with PBS and equilibrated for $60 \mathrm{~min}$ with serum-free medium $(2 \mathrm{ml} /$ well). The medium was then replaced with fresh medium alone (negative control), medium containing $1 \%$ Triton X-100 (positive control), or medium containing the secretagogue. After $30 \mathrm{~min}$ the medium was removed and the cells were incubated with fresh medium for an additional $60 \mathrm{~min}$. LDH released during both periods was measured spectrophotometrically at $340 \mathrm{~nm}$ using a kit (Sigma Chemical Co.). The amount of LDH released by the secretagogues was expressed as percent of the total cellular LDH, as determined by the paired positive controls. Release of $\geq 0.5 \%$ of the total cellular LDH was detectable.

For vital dye exclusion, cells were trypsinized $(0.05 \%$ trypsin, $0.02 \%$ EDTA; $5 \mathrm{~min}, 37^{\circ} \mathrm{C}$ ) either immediately after stimulation or after the 60-min incubation period after stimulation, and viability was counted after addition of erythrosin $B$.

Immunocytochemistry. Serous cells were seeded on human placental collagen-coated coverslips and maintained and chased for $210 \mathrm{~min}$ as described above. After incubation with either serum-free medium alone or medium containing $10^{-8} \mathrm{M}$ elastase, the cells were washed with PBS and fixed with paraformaldehyde-acetone ( $\mathrm{pH}$ 6.6). Indirect immunofluorescence was performed as described previously (30) with the MAb CS-56 which recognizes chondroitin sulfate proteoglycan (31). Mounted coverslips were examined and photographed using a fluorescence microscope (Carl Zeiss, Inc., Thornwood, NY).

Degranulation supernatant from human neutrophils. Human peripheral blood neutrophils were purified from the buffy coat fraction (Irwin Memorial Blood Bank, San Francisco, CA). Neutrophils were separated from monocytes and platelets by centrifugation $(400 \mathrm{~g}, 40$ min) through Ficoll-Paque (Pharmacia Fine Chemicals) and the remaining erythrocytes were lysed by hypotonic shock. The resulting cell population contained $\geq 95 \%$ neutrophils and was $\geq 95 \%$ viable as determined by phase microscopy and vital dye exclusion (erythrosin $B)$, respectively. The neutrophils were washed in calcium- and magnesium-free HBSS and resuspended in complete HBSS at a concentration of $0.6 \times 10^{8}$ cells $/ \mathrm{ml}$. Cells were activated by incubation with 5 $\mu \mathrm{g} / \mathrm{ml}$ cytochalasin B and $10^{-6} \mathrm{M}$ FMLP for $10 \mathrm{~min}$ at $37^{\circ} \mathrm{C}$. Cell-free degranulation supernatant was prepared by centrifugation $(400 \mathrm{~g}, 15$ min) and stored at $-70^{\circ} \mathrm{C}$.

Measurements of protease activity. Cathepsin G-like activity and elastase-like activity were measured using succinyl-L-Ala-Ala-ProPhe-4-nitroanilide and succinyl-L-Ala-Ala-Pro-Val-4-nitroanilide, respectively. Reactions were carried out at $37^{\circ} \mathrm{C}$ in PBS (pH 7.4) with a substrate concentration of $80 \mu \mathrm{g} / \mathrm{ml}$ and monitored spectrophotometrically at $394 \mathrm{~nm}$. Protease concentrations were calculated by comparison with the activity of purified proteases determined under identical conditions.

To determine the effect of protease inhibitors on the amidolytic activity, proteases were preincubated for $5 \mathrm{~min}$ either with PBS alone or with PBS containing the inhibitor.

Statistics. All values are expressed as mean \pm SEM. Statistical analysis was performed using analysis of variance and Newman-Keuls or Dunetts multiple comparison test, where appropriate (32). A $P$ value of $<0.05$ was considered significant.

\section{Results}

Basal secretion. Cultured serous cells secreted nondialyzable ${ }^{35}$ S-labeled macromolecules spontaneously and continuously. 
After the 3.5-h chase, baseline secretion decreased by $19 \pm 2 \%$ between the consecutive 30 -min sampling periods $(n=31)$. In the 210- to $240-\mathrm{min}$ time period basal secretion per culture flask ( $25 \mathrm{~cm}^{2}$ surface area) averaged $1,920 \pm 275 \mathrm{cpm}$, equivalent to $2.2 \pm 0.25 \%$ of the total incorporated nondialyzable radiolabel $(n=10)$.

Secretion induced by human neutrophil proteases. Human neutrophil cathepsin $G$ and neutrophil elastase both stimulated secretion of ${ }^{35} \mathrm{~S}$-labeled macromolecules markedly $(P$ $<0.0001$ ) in a concentration-dependent fashion (Fig. 1). The threshold concentration causing a significant increase of secretion over baseline was $\geq 10^{-10} \mathrm{M}$ for both cathepsin $\mathrm{G}$ and elastase. The maximal secretory response to both proteases was similar, although only the response to elastase reached a plateau at the concentrations used. Elastase was more potent than cathepsin $\mathrm{G}(P<0.0001)$, with responses at $10^{-8} \mathrm{M}$ of $1,810 \pm 60$ and $970 \pm 20 \%$ above baseline, respectively $(n=5)$. In contrast, histamine caused secretion with a threshold of $10^{-8} \mathrm{M}$ and a maximal secretory response of only $185 \pm 8 \%$ at $10^{-5} \mathrm{M}(P<0.0001, n=6)$. Addition of equal amounts of the vehicles of cathepsin $\mathrm{G}(0.22 \mathrm{M}$ ammonium sulfate in $0.1 \mathrm{M}$ sodium acetate, $\mathrm{pH} 5.0)$ and elastase $(0.1 \mathrm{M}$ sodium acetate, pH 5.0), respectively, had no effect on basal secretion $(-5.5 \pm 7.5$ and $-5 \pm 4 \%$, respectively; $n=5)$.

The secretion induced by neutrophil proteases was not cytotoxic. Neither cathepsin $\mathrm{G}$ nor elastase (both $10^{-7} \mathrm{M}$ ) caused a significant increase of $\mathrm{LDH}$ release above control during stimulation $(1.1 \pm 0.3,2.1 \pm 0.6$, and $0.9 \pm 0.4 \%$ of the total cellular LDH for cathepsin G, elastase, and control, respectively) or during the $60-\mathrm{min}$ period after stimulation $(0.9 \pm 0.1$, $2.5 \pm 0.4$, and $1.8 \pm 0.2 \%$, respectively) ( $n=6$ each). Cell viability as determined by vital dye exclusion was $\geq 97 \%$ for stimulated and unstimulated cells both immediately and $60 \mathrm{~min}$ after stimulation. In addition, examination of the culture flasks by phase microscopy revealed an undisturbed cell monolayer without morphologic signs of cytotoxicity.

The secretory response to $10^{-8} \mathrm{M}$ cathepsin $\mathrm{G}(970 \pm 20 \% ; n$ $=5$ ) was reduced by 10 and $50 \mu \mathrm{g} / \mathrm{ml}$ chymostatin $(245 \pm 35$ and $100 \pm 7 \%)$, respectively $(P<0.01, n=5)$, and was abolished by $100 \mu \mathrm{g} / \mathrm{ml}$ soybean trypsin inhibitor $(29 \pm 20 \% ; P$ $<0.01, n=5$ ) (Fig. 2). The secretory response caused by $10^{-8}$ $\mathrm{M}$ elastase $(1,810 \pm 60 \%)$ was reduced significantly by $10^{-4} \mathrm{M}$

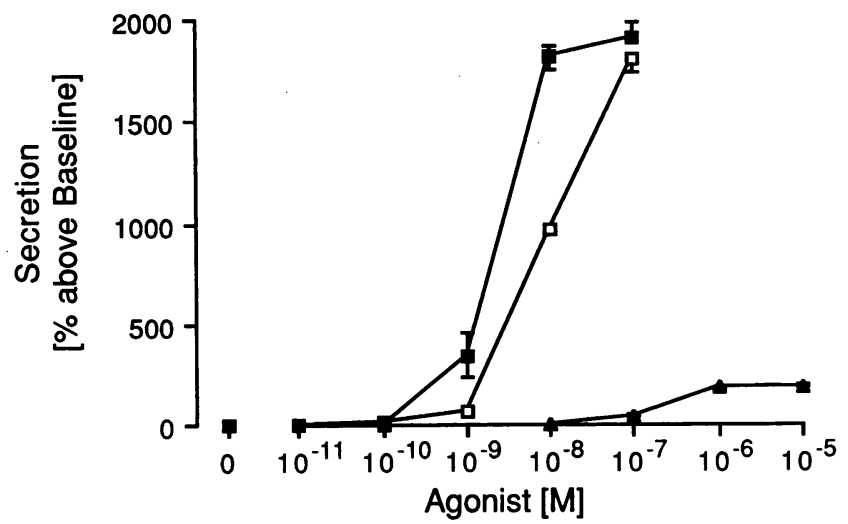

Figure 1. Effects of human neutrophil cathepsin G (open squares) and elastase (solid squares) and of histamine (closed triangles) on secretion of ${ }^{35} \mathrm{~S}$-labeled macromolecules from cultured tracheal gland serous cells. Secretion is stimulated markedly by cathepsin $\mathrm{G}$ and elastase $(P<0.0001, n=5)$, whereas histamine has a comparatively small effect $(P<0.0001, n=6)$. Values are mean \pm SEM. a

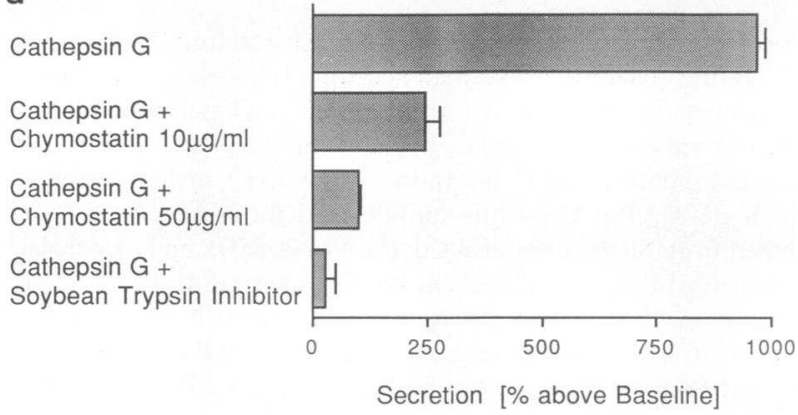

b

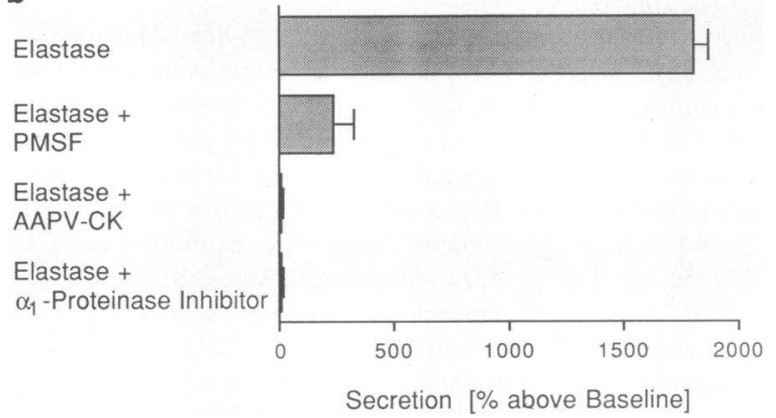

Figure 2. Effect of active site inhibitors on secretion induced by $10^{-8}$ $M$ human neutrophil cathepsin $G(a)$ and elastase $(b)$. Soybean trypsin inhibitor, $100 \mu \mathrm{g} / \mathrm{ml}$; PMSF, $10^{-4} \mathrm{M} ; N$-methoxysuccinyl-AlaAla-Pro-Val-chloromethylketone ( $A A P V-C K), 10^{-5} \mathrm{M} ; \alpha_{1}$-proteinase inhibitor, $100 \mu \mathrm{g} / \mathrm{ml}$. Values are mean \pm SEM, $n=5$.

PMSF $(240 \pm 85 \% ; P<0.01, n=5)$ and was blocked completely by $10^{-5} \mathrm{M} \mathrm{N}$-methoxysuccinyl-Ala-Ala-Pro-Val-chloromethylketone and by $100 \mu \mathrm{g} / \mathrm{ml} \alpha_{1}$-proteinase inhibitor (13 \pm 4 and $-4 \pm 3 \%$, respectively; $P<0.01, n=5$ ). The inhibitors had no effect on basal secretion $(3 \pm 5,14 \pm 8,3 \pm 4,0 \pm 5$, and $-1 \pm 2 \%$ for chymostatin $(50 \mu \mathrm{g} / \mathrm{ml})$, soybean trypsin inhibitor, PMSF, $\mathrm{N}$-methoxysuccinyl-Ala-Ala-Pro-Val-chloromethylketone, and $\alpha_{1}$-proteinase inhibitor, respectively; $n=5$ each). The inhibitory effect of the protease inhibitors on the protease-induced secretory response was similar to their effect on the amidolytic activity of the proteases. Thus, the amidolytic activity of cathepsin $\mathrm{G}$ was reduced $90 \%$ by $10 \mu \mathrm{g} / \mathrm{ml}$ chymostatin and $>90 \%$ (remaining activity below the limit of detection) by $50 \mu \mathrm{g} / \mathrm{ml}$ chymostatin or $100 \mu \mathrm{g} / \mathrm{ml}$ soybean trypsin inhibitor. The amidolytic activity of elastase was inhibited $96 \%$ by $10^{-4} \mathrm{M}$ PMSF and $\geq 99 \%$ by $10^{-5} \mathrm{M} N$-methoxysuccinyl-Ala-Ala-Pro-Val-chloromethylketone or $100 \mu \mathrm{g} / \mathrm{ml}$ $\alpha_{1}$-proteinase inhibitor. This correlation between the protease inhibitor-induced reduction of the secretory response and the inhibition of the amidolytic activity suggests that the active catalytic site of the proteases is required for inducing a secretory response.

Analysis of secreted radiolabeled macromolecules. Gel filtration chromatography of basal secretions yielded a single peak in the void volume (Fig. $3 a$ ). Exclusion from Superose 6 in $4 \mathrm{M}$ guanidine $/ 0.5 \% \mathrm{CHAPS}$ indicates the presence of high-molecular-weight $\left(>10^{6} \mathrm{D}\right)$ glycoconjugates. Stimulation of secretion from serous cells with $10^{-6} \mathrm{M}$ histamine increased the amount of radiolabel eluting in this void volume peak (Fig. 3 a). Similarly, stimulation of secretion with low concentrations of cathepsin $\mathrm{G}\left(3 \times 10^{-9} \mathrm{M}\right)$ or elastase $\left(10^{-9} \mathrm{M}\right)$ increased the amount of radiolabeled glycoconjugate eluting in the void volume (Fig. $3 b$ and $c$ ). However, higher concentra- 

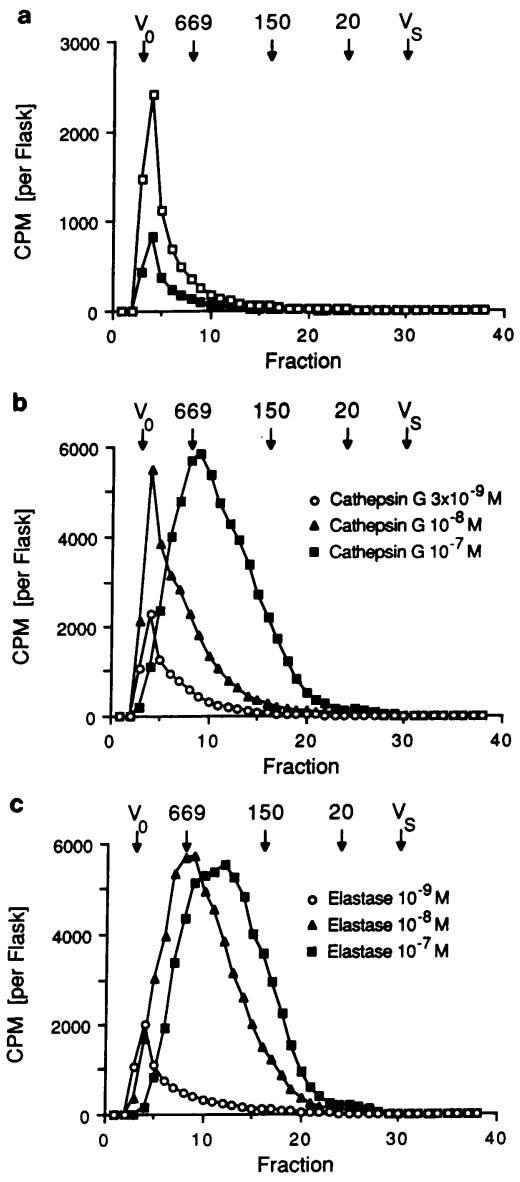

Figure 3. Gel filtration chromatography (Superose 6) of ${ }^{35}$ S-labeled material secreted from cultured serous cells under basal conditions (solid squares) and in response to histamine $\left(10^{-6} \mathrm{M}\right.$; open squares) (a) and to increasing concentrations of human neutrophil cathepsin $\mathbf{G}(b)$ and elastase $(c)$. The arrows mark the elution position of blue dextran $\left(V_{o}\right)$, thyroglobulin (669 $k D)$, alcohol dehydrogenase $(150 \mathrm{kD})$, soybean trypsin inhibitor (20 $k D)$, and $\mathrm{Na}_{2}{ }^{35} \mathrm{SO}_{4}\left(V_{s}\right)$, respectively.

tions of the proteases caused not only an increase in the total amount of radiolabeled material secreted, but also a decrease in the average apparent molecular weight, suggesting degradation of secreted glycoconjugates.

Glycosidase digestions of basal secretions (Fig. $4 a$ ) and secretions induced by histamine $\left(10^{-6} \mathrm{M}\right.$; Fig. $\left.4 \mathrm{~b}\right)$, human neutrophil cathepsin $\mathrm{G}\left(10^{-7} \mathrm{M}\right.$; Fig. $\left.4 \mathrm{c}\right)$, and elastase $\left(10^{-7}\right.$ $\mathrm{M}$; Fig. $4 d$ ) gave identical results: chondroitinase $\mathrm{ABC}$ and AC shifted $\sim 90 \%$ of the radioactivity to the salt peak on Superose 6. These findings demonstrate that the radiolabeled glycoconjugate secreted under baseline conditions and in response to all three agonists is chondroitin sulfate proteoglycan.

Degradation of serous cell secretions by neutrophil proteases. To verify that the apparent lower molecular weight of protease-induced secretions was due to degradation, we examined the effect of neutrophil proteases on partially purified high molecular weight chondroitin sulfate. To obtain secreted proteoglycan unexposed to proteases, serous cells were stimulated with histamine $\left(10^{-5} \mathrm{M}\right)$ in the presence of the cAMPphosphodiesterase inhibitor 3-isobutyl-1-methylxanthine $\left(10^{-5} \mathrm{M}\right)$ to give a maximal histamine-induced response (unpublished observations). The secreted high-molecular-weight chondroitin sulfate proteoglycan was partially purified by $\mathrm{Su}-$ perose 6 gel filtration chromatography. Incubation of aliquots of this chondroitin sulfate proteoglycan with $10^{-7} \mathrm{M}$ elastase and $10^{-6} \mathrm{M}$ cathepsin $\mathrm{G}$ caused degradation, with a resulting molecular weight distribution (Fig. 5) similar to that of protease-induced secretions (Fig. $3 b$ and $c$ ).

Cellular glycoconjugate pools. Gel filtration analysis of glycoconjugates extracted from cell pellets of serous cells demon-
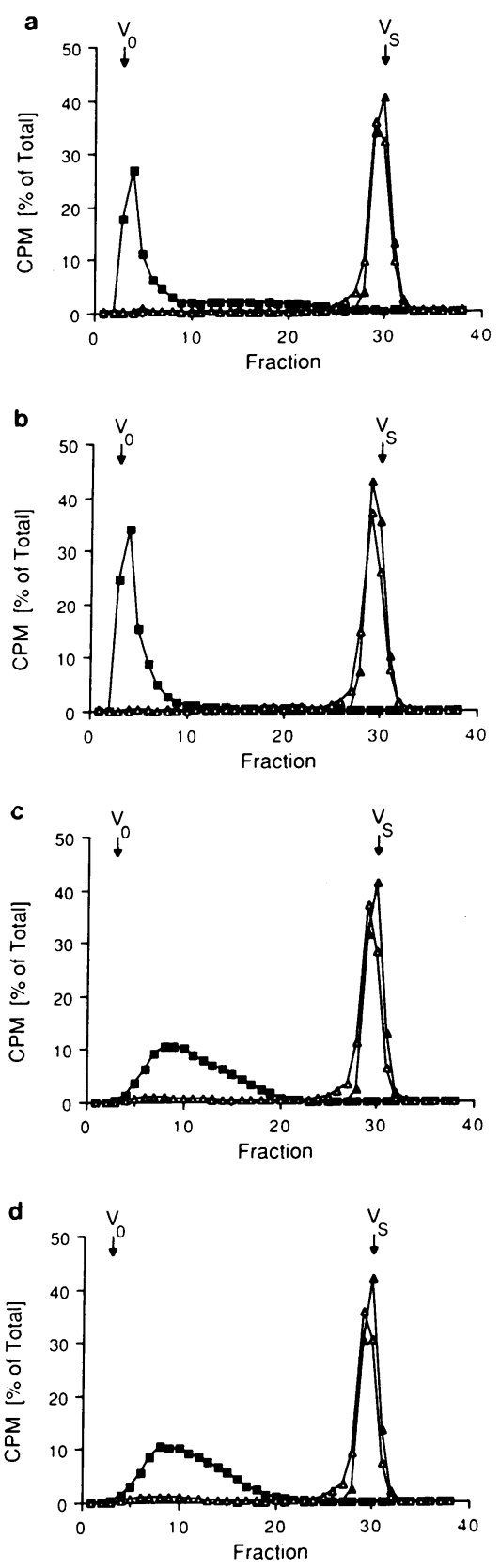

Figure 4. Glycosidase digestions of ${ }^{35} \mathrm{~S}$-labeled glycoconjugates secreted from cultured serous cells under basal conditions $(a)$ and in response to $10^{-5} \mathrm{M}$ histamine (b) and to $10^{-7} \mathrm{M}$ human neutrophil cathepsin $\mathbf{G}(c)$ and elastase $(d)$. Gel filtration chromatography (Superose 6) was performed after incubation with buffer alone (solid squares), chondroitinase ABC (solid triangles), or chondroitinase AC (open triangles).

strated the presence of two pools different in molecular size (Fig. $6 a$ ). In the case of unstimulated cells, $\sim 45 \%$ of the incorporated radiolabel eluted in the void volume of Superose 6. Molecular weight distribution and sensitivity to both chondroitinase $\mathrm{ABC}$ and $\mathrm{AC}$ (Fig. $6 \mathrm{~b}$ ) were identical to baseline and histamine-induced secretions, suggesting that this pool represents granule-associated chondroitin sulfate proteoglycan. Stimulation of cells with $10^{-8} \mathrm{M}$ elastase depleted this pool by $\geq 80 \%$.

A second pool containing $\sim 55 \%$ of the incorporated radiolabel eluted in the included volume of Superose 6, with an average molecular weight of $\sim 1.6 \times 10^{5} \mathrm{D}$. Glycosidase digestions (Fig. 6 c) showed that this pool contains only about $10 \%$ chondroitin sulfate proteoglycan, $\sim 65 \%$ dermatan sulfate proteoglycan, and $\sim 25 \%$ material not digested by chondroitinase $\mathrm{ABC}$, i.e., other radiolabeled glycoconjugates or proteins. This pool was not altered by stimulation of the cells 


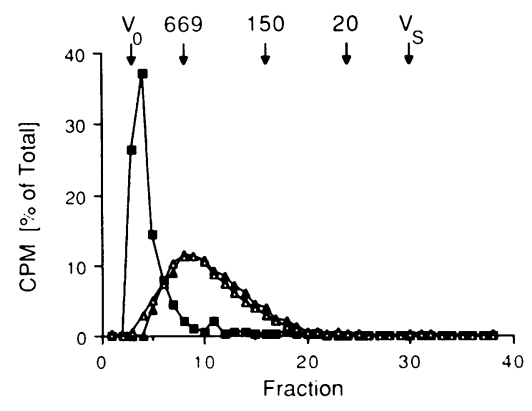

Figure 5. Degradation of serous cell secretions by human neutrophil proteases. Chondroitin sulfate proteoglycan partially purified from histamine-induced serous cell secretions was analyzed after incubation with buffer alone (solid squares), $10^{-6} \mathrm{M}$ cathepsin $\mathbf{G}$ (solid triangles), or $10^{-7} \mathrm{M}$ elastase (open triangles).

and may represent material on the cell surface, in lysosomes or other nonsecretory cell organelles.

Immunocytochemistry. Staining of unstimulated serous cells with the MAb CS-56, which recognizes chondroitin sulfate proteoglycan (31), resulted in punctate staining that spared the nucleus, suggesting that chondroitin sulfate was localized within cytoplasmic granules (Fig. 7 a). Controls in which the primary or the secondary antibody was omitted showed no staining. Incubation of cells with $10^{-8} \mathrm{M}$ elastase completely abolished punctate staining (Fig. 7 b), suggesting that elastase had caused degranulation.

Secretion induced by degranulation supernatant from human neutrophils. Degranulation supernatant from human peripheral blood neutrophils stimulated secretion from cul-
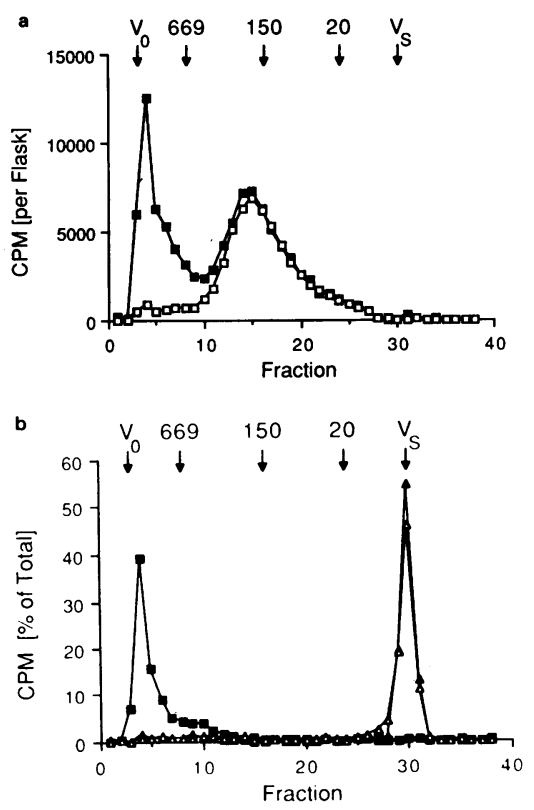

Figure 6. $a$, Gel filtration chromatography of glycoconjugates extracted from pellets of cells incubated with buffer (solid squares) or stimulated with $10^{-8} \mathrm{M}$ elastase (open squares). $b$, Gel filtration analysis of the high-molecularweight pool (fractions 3-8 from Fig. $6 a$ ) and lower-molecular-weight pool (fractions 9-25 from Fig. $6 a)(c)$ from pellets of unstimulated cells after incubation with buffer alone (solid squares), chondroitinase $\mathrm{ABC}$ (solid triangles), or AC (open triangles).
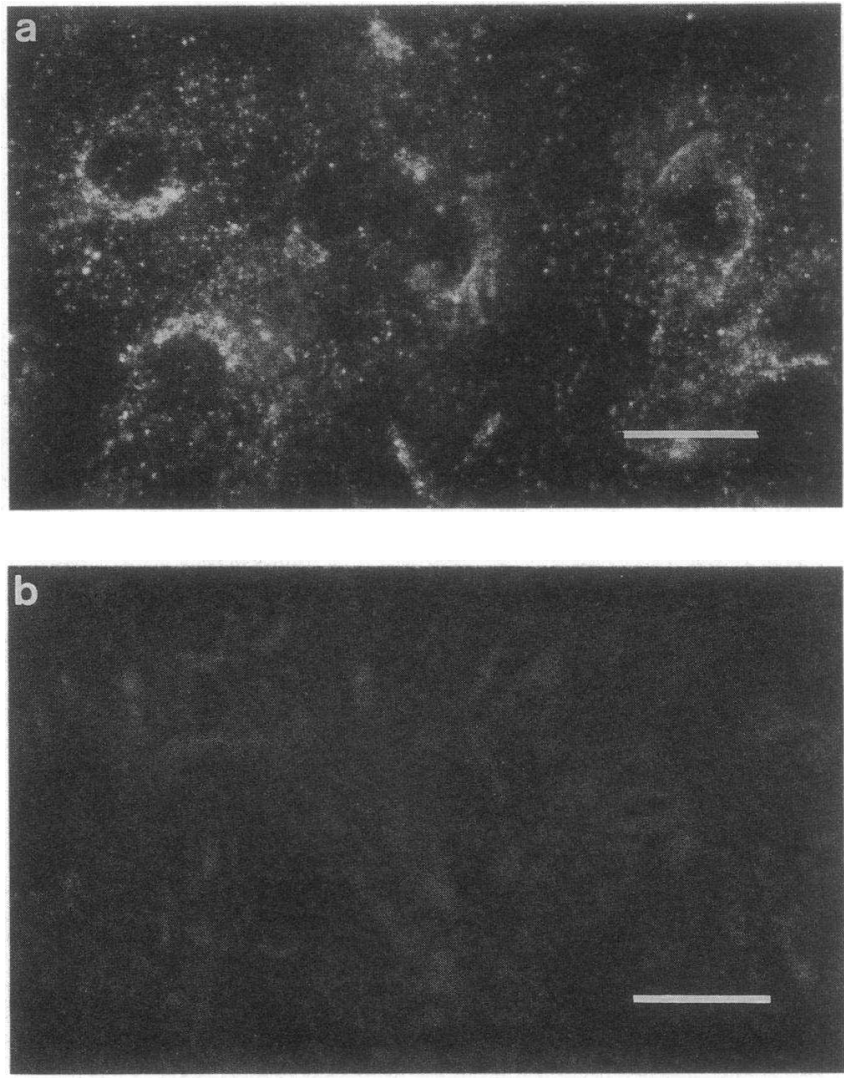

Figure 7. Indirect immunofluorescence staining of serous cells with a MAb directed against chondroitin sulfate proteoglycan ( $b a r=10$ $\mu \mathrm{m}) . a$, Unstimulated cells show punctate cytoplasmic staining with sparing of the nuclei, suggesting that chondroitin sulfate proteoglycan is associated with cytoplasmic granules. $b$, Incubation of cells with $10^{-8} \mathrm{M}$ elastase abolishes staining, suggesting that elastase has caused degranulation.

tured serous cells markedly. When degranulation supernatant from $10^{5}$ neutrophils was added per $\mathrm{ml}$ of incubation medium of serous cells, the secretory response averaged $2,095 \pm 54 \%$ above baseline $(n=6, P<0.0001)$. The response was partially inhibited by addition of $10^{-5} \mathrm{M} \mathrm{N}$-methoxysuccinyl-Ala-AlaPro-Val-chloromethylketone (remaining response $363 \pm 22 \%$ ) and was further reduced by addition of $50 \mu \mathrm{g} / \mathrm{ml}$ chymostatin $(102 \pm 19 \%)$. The magnitude of the secretory response to the final concentration of elastase $\left(0.5 \times 10^{-8} \mathrm{M}\right)$ and cathepsin $\mathrm{G}$ $\left(10^{-9} \mathrm{M}\right)$ in the incubation medium containing neutrophil supernatant, as determined by measurement of amidolytic activity, agreed well with the responses obtained using the purified enzymes. Concentrations of cytochalasin B and FMLP equal to those present in supernatant from activated neutrophils had no effect on baseline secretion $(-0 \pm 8 \% ; n=4)$.

\section{Discussion}

We demonstrated in this study that the human neutrophil proteases cathepsin $\mathrm{G}$ and elastase markedly stimulate degranulation of cultured tracheal gland serous cells. The secretory response to these proteases is noncytotoxic, requires catalytically active enzymes, and is $>10$-fold larger than the secre- 
tory response evoked by agonists such as histamine. Cathepsin $G$ and elastase in supernatant obtained by degranulation of human peripheral blood neutrophils cause a secretory response similar in magnitude to that caused by the purified enzymes. We also show that the neutrophil proteases degrade the predominant ${ }^{35} \mathrm{~S}$-labeled serous cell secretory product, chondroitin sulfate proteoglycan. Thus, we provide the first evidence that neutrophil proteases cause degranulation of airway submucosal gland cells, the presumed major source of airway secretions in humans.

Together with the mast cell-derived protease chymase (24), neutrophil proteases are the most potent secretagogues for cultured serous cells in regard to both threshold concentration and magnitude of the response. Concentrations of other agonists such as histamine, prostaglandins, and $\beta$-adrenergic agonists in excess of $10^{-8} \mathrm{M}$ are required to induce secretory responses $(25,33,34)$, whereas the threshold concentration for proteases $\left(\geq 10^{-10} \mathrm{M}\right)$ is lower by two orders of magnitude. Perhaps more significantly, proteases induce a maximal secretory response $>10$-fold larger than that of other agonists, causing $\geq 80 \%$ depletion of ${ }^{35} \mathrm{~S}$-labeled macromolecules from serous cells.

Suggestive in vivo evidence for an effect of proteases on submucosal glands has been reported in abstract form by Hahn et al. (35). These investigators found that repeated intratracheal administration of porcine pancreatic elastase to ferrets in vivo increased the turnover of radiolabeled material in airway submucosal glands. Several lines of evidence have previously suggested an effect of proteases on cells of the airway surface layer. Elastases such as neutrophil elastase, pancreatic elastase, and Pseudomonas aeruginosa elastase, but not chymotryptic enzymes such as neutrophil cathepsin $G$ or pancreatic chymotrypsin, release radiolabeled material from rabbit and hamster tracheal explants (36-38), tissues lacking submucosal glands (39). Whether the release of this material is due primarily to protease-induced exocytosis or to hydrolysis of protease-sensitive molecules already present on the cell surface is not clear. Several studies provide light- and electron-microscopic evidence of protease-induced degranulation of goblet cells in vivo and in vitro $(18,37,38)$. However, other studies using cultured tracheal epithelial cells lacking secretory granules (19), cultured epithelial cells with goblet-cell phenotype (20), and tracheal explants (21) have shown protease-stimulated release of glycoconjugates associated with the cell surface. In comparison to the concentrations of proteases needed to cause these effects on cells of the airway surface layer, the concentrations of neutrophil cathepsin G, elastase, and mast cell chymase (24) sufficient to produce a response in cultured serous cells $\left(\geq 10^{-10} \mathrm{M}=3 \mathrm{ng} / \mathrm{ml}\right)$ are strikingly lower. The threshold concentration of neutrophil elastase for release of surface molecules from cultured hamster tracheal epithelial cells lies between 0.33 and $3.3 \times 10^{-7} \mathrm{M}(1-10 \mu \mathrm{g} / \mathrm{ml})(20)$. Thus, the threshold effects reported in the current study are seen at $\sim 1,000$-fold lower concentrations of neutrophil elastase. The threshold concentrations we report are also lower than those of chymotrypsin and chymase $\left(\geq 10^{-7} \mathrm{M}\right)$ needed to cause degranulation of rat peritoneal mast cells (40), and are lower than the concentrations of cathepsin $\mathrm{G}\left(\geq 3 \times 10^{-8} \mathrm{M}\right)$ needed to induce platelet activation (41).

We present several lines of evidence suggesting that the protease-induced secretory response of serous cells is due to exocytosis of cytoplasmic granules: $(a)$ the neutrophil pro- tease-induced response is noncytotoxic, so release of radiolabeled glycoconjugates from the cytoplasm is unlikely; $(b)$ the sulfated glycoconjugate secreted in response to proteases is the same type of proteoglycan (chondroitin sulfate) released from cultured serous cells in response to cAMP-dependent activation by receptor-mediated agonists such as histamine (33) and $\beta$-adrenergic agonists (42) and from bovine tracheal explants in short-term culture in response to $\beta$-adrenergic agonists (43); (c) the serous cell glycoconjugate pool containing chondroitin sulfate is $\geq 80 \%$ depleted by elastase, whereas a second glycoconjugate pool containing dermatan sulfate proteoglycan, usually an extracellular glycoconjugate (44), remains unaltered; and $(d)$ immunocytochemical studies demonstrate the presence of chondroitin sulfate proteoglycan within cytoplasmic granules of serous cells before stimulation and complete loss of these granules in response to elastase.

The mechanism by which proteases stimulate degranulation of serous cells remains to be determined. Protease-induced degranulation of serous cells requires the active catalytic site of the proteases, as does cathepsin G-induced activation of platelets (41) and chymase-induced degranulation of mast cells (45). Thus, these serous cell secretagogue effects stand in contrast to reported noncatalytic effects of cathepsin $G$ and elastase on endothelial cell injury (46) änd albumin flux $(47,48)$. Chymotryptic proteases related to cathepsin $\mathrm{G}$, chymotrypsin, and chymase, have been known to cause degranulation of mast cells for $>25 \mathrm{yr}(40,49,50)$, but the mechanism of protease-induced mast cell activation is still unknown. Specific binding of chymotrypsin to mast cells does not occur, implying that the activation by chymotrypsin does not involve a simple ligand-receptor binding (45). In contrast, low affinity binding sites for cathepsin $G$ and elastase mediating endocytosis into macrophages and high affinity receptor binding sites for elastase on fibroblasts not mediating endocytosis have been described (51-53). Intracellular proteases have been shown to be required for exocytosis and other cellular functions in some cells such as mast cells (54-57), so it is conceivable that exogenous proteases may mimic these endogenous proteases if they are endocytosed. Alternatively, the catalytic activity of the proteases may be directed at targets on the cell surface.

In addition to stimulating secretion, both cathepsin $G$ and elastase degrade the secreted chondroitin sulfate proteoglycan, reducing the average molecular weight from $>10^{6} \mathrm{D}$ to an average of $3.5 \times 10^{5} \mathrm{D}$ in the case of secretions stimulated by $10^{-7} \mathrm{M}$ elastase. The highly anionic nature of the secreted chondroitin sulfate proteoglycan (42) may facilitate this degradation by cationic neutrophil proteases $(58)$. The degradation of serous cell-derived chondroitin sulfate proteoglycan by neutrophil proteases is likely to cause an alteration of rheological properties, an increase of colloid osmotic pressure, and, possibly, the modification of biologic functions.

Neutrophils contain $\sim 2-4 \mu \mathrm{g}$ cathepsin $\mathrm{G}(59,60)$ and $1-2 \mu \mathrm{g}$ elastase.per $10^{6}$ cells $(61,62)$. Thus, the release of $10 \%$ of the proteases from $10^{5}$ neutrophils $/ \mathrm{cm}^{3}$ of submucosal tissue may be sufficient to cause a significant secretory response. Because the number of neutrophils found in the submucosa of dogs, particularly during airway inflammation, is considerably higher $\left(0.5 \times 10^{7} / \mathrm{cm}^{3}\right.$ before and $2 \times 10^{7} / \mathrm{cm}^{3}$ after ozone exposure [4]), a secretory response appears likely even if $>99 \%$ of the proteases are inhibited by endogenous antiproteases. In patients with cystic fibrosis and chronic bronchitis, conditions characterized by excessive and abnormal airway 
secretions, sputum concentrations of uninhibited cathepsin $G$ and elastase are known to be increased markedly and to greatly exceed the concentrations used in this study (10).

In summary, we have demonstrated that the neutrophil proteases cathepsin $\mathrm{G}$ and elastase are potent secretagogues for airway gland serous cells. In comparison to other agonists such as prostaglandins, histamine, and neurotransmitters, neutrophil proteases are more potent with respect to both threshold concentration and magnitude of the secretory response and are equipotent only to mast cell chymase. In addition, both proteases degrade the predominant secretory product, chondroitin sulfate proteoglycan. These results suggest a role for neutrophil proteases in the pathogenesis of increased and abnormal secretions associated with inflammatory airway diseases. In addition, because serous cells are the source of antileukoprotease (63), a potent protease inhibitor found in airway secretions, the sensitivity of serous cells to proteases provides a potential regulatory feedback mechanism in the defense of the airways.

\section{Acknowledgments}

The authors thank Lynne Calonico for photographic assistance and Patty Snell for editorial assistance.

This study was supported in part by National Institutes of Health (NIH) Program Project grant HL-24136 and by a grant from the Cystic Fibrosis Foundation Research and Development Program. Dr. Sommerhoff was the recipient of fellowships from the Deutsche Forschungsgemeinschaft and the German Academic Exchange Service. Dr. Caughey was supported by NIH Clinical Investigator Award HL-07136.

\section{References}

1. Reynolds, H. Y., and W. W. Merrill. 1981. Airway changes in young smokers that may antedate chronic obstructive lung disease. Med. Clin. North Am. 65:667-689.

2. Hunninghake, G. W., J. E. Gadek, O. Kawanami, V. J. Ferrans, and R. G. Crystal. 1979. Inflammatory and immune processes in the human lung in health and disease: evaluation by bronchoalveolar lavage. Am. J. Pathol. 97:149-206.

3. Seltzer, J., B. G. Bigby, M. Stulbarg, M. J. Holtzman, J. A. Nadel, I. F. Ueki, G. D. Leikauf, E. J. Goetzl, and H. A. Boushey. 1986. Ozone-induced changes in bronchial reactivity to methacholine and airway inflammation in humans. J. Appl. Physiol. 60:1321-1326.

4. Holtzman, M. J., L. M. Fabbri, P. M. O'Byrne, B. D. Gold, H. Aizawa, E. H. Walters, S. E. Alpert, and J. A. Nadel. 1983. Importance of airway inflammation for the hyperresponsiveness induced by ozone. Am. Rev. Respir. Dis. 127:686-690.

5. Seltzer, J., P. D. Scanlon, J. M. Drazen, R. H. Ingram, Jr., and L. Reid. 1984. Morphologic correlation of physiologic changes caused by $\mathrm{SO}_{2}$-induced bronchitis in dogs: the role of inflammation. Am. Rev. Respir. Dis. 129:790-797.

6. Shore, S. A., S. T. Kariya, K. Anderson, W. Skornik, H. A. Feldman, J. Pennington, J. Godleski, and J. M. Drazen. 1987. Sulfurdioxide-induced bronchitis in dogs: effects on airway responsiveness to inhaled and intravenously administered methacholine. Am. Rev. Respir. Dis. 135:840-847.

7. Phipps, R. J., S. M. Denas, M. W. Sielczak, and A. Wanner. 1986. Effects of $0.5 \mathrm{ppm}$ ozone on glycoprotein secretion, ion and water fluxes in sheep trachea. J. Appl. Physiol. 60:918-927.

8. Weissmann, G., R. B. Zurier, and S. Hoffstein. 1972. Leukocytic proteases and the immunological release of lysosomal enzymes. Am. J. Pathol. 68:539-563.
9. Ohlsson, K Ke, and I. Olsson. 1977. The extracellular release of granulocyte collagenase and elastase during phagocytosis and inflammatory processes. Scand. J. Haematol. 19:145-152.

10. Goldstein, W., and G. Döring. 1986. Lysosomal enzymes from polymorphonuclear leukocytes and proteinase inhibitors in patients with cystic fibrosis. Am. Rev. Respir. Dis. 134:49-56.

11. Suter, S., U. B. Schaad, H. Tegner, K. Ohlsson, D. Desgrandchamps, and F. A. Waldvogel. 1986. Levels of free granulocyte elastase in bronchial secretions from patients with cystic fibrosis: effect of antimicrobial treatment against Pseudomonas aeruginosa. J. Infect. Dis. 153:902-909.

12. Ohlsson, K., and H. Tegner. 1975. Granulocyte collagenase, elastase and plasma protease inhibitors in purulent sputum. Eur. $J$. Clin. Invest. 5:221-227.

13. Stockley, R. A., and D. Burnett. 1979. Alpha 1-antitrypsin and leukocyte elastase in infected and non-infected sputum. Am. Rev. Respir. Dis. 120:1081-1086.

14. Weitz, J. I., K. A. Crowley, S. L. Landman, B. I. Lipman, and J. $\mathrm{Yu}$. 1987. Increased neutrophil elastase activity in cigarette smokers. Ann. Intern. Med. 107:680-682.

15. Janoff, A., L. Raju, and R. Dearing. 1983. Levels of elastase activity in bronchoalveolar lavage fluids of healthy smokers and nonsmokers. Am. Rev. Respir. Dis. 127:540-544.

16. Tetley, T. D., S. F. Smith, G. H. Burton, A. J. Winning, N. T. Cooke, and A. Guz. 1987. Effects of cigarette smoking and drugs on respiratory tract proteases and antiproteases. Eur. J. Respir. Dis. Suppl. 153:93-102.

17. Mullen, J. B. M., J. L. Wright, B. R. Wiggs, P. D. Pare, and J. C. Hogg. 1987. Structure of central airways in current smokers and exsmokers with and without mucus hypersecretion: relationship to lung function. Thorax. 42:843-848.

18. Breuer, R., T. G. Christensen, E. C. Lucey, P. J. Stone, and G. L. Snider. 1987. An ultrastructural morphometric analysis of elastase-treated hamster bronchi shows discharge followed by progressive accumulation of secretory granules. Am. Rev. Respir. Dis. 136:698703.

19. Varsano, S., C. B. Basbaum, L. S. Forsberg, D. B. Borson, G. Caughey, and J. A. Nadel. 1987. Dog tracheal epithelial cells in culture synthesize sulfated macromolecular glycoconjugates and release them from the cell surface upon exposure to extracellular proteinases. Exp. Lung Res. 13:157-184.

20. Kim, K. C., K. Wasano, R. M. Niles, J. E. Schuster, P. J. Stone, and J. S. Brody. 1987. Human neutrophil elastase releases cell surface mucins from primary cultures of hamster tracheal epithelial cells. Proc. Natl. Acad. Sci. USA. 84:9304-9308.

21. Breuer, R., T. G. Christensen, R. M. Niles, P. J. Stone, and G. L. Snider. 1989. Human neutrophil elastase causes glycoconjugate release from the cell surface of hamster trachea in organ culture. Am. Rev. Respir. Dis. 139:779-782.

22. Reid, L. 1960. Measurement of the bronchial mucous gland layer: a diagnostic yardstick in chronic bronchitis. Thorax. 15:132141.

23. Sobonya, R. E., and L. M. Taussig. 1986. Quantitative aspects of lung pathology in cystic fibrosis. Am. Rev. Respir. Dis. 134:290-295.

24. Sommerhoff, C. P., G. H. Caughey, W. E. Finkbeiner, S. C. Lazarus, C. B. Basbaum, and J. A. Nadel. 1989. Mast cell chymase: a potent secretagogue for airway gland serous cells. J. Immunol. 142:2450-2456.

25. Finkbeiner, W. E., J. A. Nadel, and C. B. Basbaum. 1986. Establishment and characterization of a cell line derived from bovine tracheal glands. In Vitro Cell. \& Dev. Biol. 22:561-567.

26. Basbaum, C. B., L. S. Forsberg, A. Paul, C. P. Sommerhoff, and W. E. Finkbeiner. 1987. Studies of tracheal secretion using serous cell cultures and monoclonal antibodies. Biorheology. 24:585-588.

27. Jacquot, J., E. Puchelle, C. B. Basbaum, and W. E. Finkbeiner. 1986. Secretion of lysozyme by bovine tracheal serous cells in culture. Am. Rev. Respir. Dis. 133:A296. (Abstr.) 
28. Coleman, D. L., I. K. Tuet, and J. H. Widdicombe. 1984 Electrical properties of dog tracheal epithelial cells grown in monolayer culture. Am. J. Physiol. 246:C355-359.

29. Hascall, V. C., and S. W. Sajdera. 1970. Physical properties and polydispersity of proteoglycan from bovine nasal cartilage. J. Biol. Chem. 245:4920-4930.

30. Basbaum, C. B., J. Mann, A. Chow, and W. E. Finkbeiner. 1984. Monoclonal antibodies as probes for unique antigens in secretory cells of mixed exocrine organs. Proc. Natl. Acad. Sci. USA. 81:4419-4423

31. Avnur, Z., and B. Geiger. 1984. Immunocytochemical localization of native chondroitin-sulfate in tissue and cultured cells using specific monoclonal antibodies. Cell. 38:811-822.

32. Zar, J. H. 1984. Biostatistical Analysis. 2nd ed. Prentice-Hall Englewood Cliffs, NJ. 620 pp.

33. Sommerhoff, C. P., W. E. Finkbeiner, J. A. Nadel, and C. B. Basbaum. 1987. Mediators of anaphylaxis stimulate ${ }^{35}$ S'labeled macromolecule secretion from cultured bovine tracheal gland serous cells. Bull. Eur. Physiopathol. Respir. 23(Suppl 12):363s. (Abstr.)

34. Sommerhoff, C. P., W. E. Finkbeiner, J. A. Nadel, and C. B. Basbaum. 1987. Prostaglandin $\mathrm{D}_{2}$ and prostaglandin $\mathrm{E}_{2}$ stimulate ${ }^{35} \mathrm{~S}$ labeled macromolecule secretion from cultured bovine tracheal gland serous cells. Am. Rev. Respir. Dis. 135:A363. (Abstr.)

35. Hahn, H. L., A. Weigt, B. Damrich-Grampp, A. Seidl, and M. Lang. 1988. Elastase increases turnover of ${ }^{35} \mathrm{~S}$-labeled macromolecules in submucosal glands. Am. Rev. Respir. Dis. 137:203. (Abstr.)

36. Niles, R. M., T. G. Christensen, R. Breuer, P. J. Stone, and G. L. Snider. 1986. Serine proteases stimulate mucous glycoprotein release from hamster tracheal ring organ culture. J. Lab. Clin. Med. 108:489-497.

37. Boat, T. F., P. W. Cheng, J. D. Klinger, C. M. Liedtke, and B. Tandler. 1984. Proteinases release mucins from airways goblet cells. Ciba Found. Symp. 109:72-87.

38. Klinger, J. D., B. Tandler, C. M. Liedtke, and T. F. Boat. 1984. Proteinases of Pseudomonas aeruginosa evoke mucin release by tracheal epithelium. J. Clin. Invest. 74:1669-1678.

39. Jeffery, P. K. 1983. Morphologic features of airway surface epithelial cells and glands. Am. Rev. Respir. Dis. 128:S14-20.

40. Schick, B., K. F. Austen, and L. B. Schwartz. 1984. Activation of rat serosal mast cells by chymase, an endogenous secretory granule protease. J. Immunol. 132:2571-2577.

41. Selak, M. A., M. Chignard, and J. B. Smith. 1988. Cathepsin G is a strong platelet agonist released by neutrophils. Biochem. J 251:293-299.

42. Paul, A., J. Picard, M. Mergey, D. Veissiere, W. E. Finkbeiner, and C. B. Basbaum. 1988. Glycoconjugates secreted by bovine trachea serous cells in culture. Arch. Biochem. Biophys. 260:75-84.

43. Escudier, E. F., L. S. Forsberg, and C. B. Basbaum. 1987. Chondroitin sulfate is a secretory product of tracheal gland serous cells in vivo as well as in culture. J. Cell Biol. 105:330a. (Abstr.)

44. Ruoslahti, E. 1988. Structure and biology of proteoglycans. Annu. Rev. Cell. Biol. 4:229-255.

45. Schick, B., and K. F. Austen. 1986. Rat serosal mast cell degranulation mediated by chymase, an endogenous secretory granule protease: active site-dependent initiation at $1^{\circ} \mathrm{C}$. J. Immunol. 136:3812-3818.

46. Smedly, L. A., M. G. Tonnesen, R. A. Sandhaus, C. Haslett, L. A. Guthrie, R. B. Johnston, Jr., P. M. Henson, and G. S. Worthen. 1986. Neutrophil-mediated injury to endothelial cells. Enhancement by endotoxin and essential role of neutrophil elastase. J. Clin. Invest. $77: 1233-1243$.
47. Peterson, M. W., and D. M. Shasby. 1987. Neutrophil cathep$\sin \mathrm{G}$ increases albumin movement across a cultured endothelium. Fed. Proc. 46:1399. (Abstr.)

48. Peterson, M. W., P. Stone, and D. M. Shasby. 1987. Cationic neutrophil proteins increase transendothelial albumin movement. $J$. Appl. Physiol. 62:1521-1530.

49. Lagunoff, D., E. Y. Chi, and H. Wan. 1975. Effects of chymotrypsin and trypsin on rat peritoneal mast cells. Biochem. Pharmacol. 24:1573-1578.

50. Uvnäs, B., and J. Antonsson. 1963. Triggering action of phosphatidase $A$ and chymotrypsins on degranulation of rat mesentery mast cells. Biochem. Pharmacol. 12:867-873.

51. Campbell, E. J., R. R. White, R. J. Rodriguez, and C. Kuhn. 1979. Receptor-mediated binding and internalization of leukocyte elastase by alveolar macrophages in vitro. J. Clin. Invest. 64:824-833.

52. Campbell, E. J. 1982. Human leukocyte elastase, cathepsin G and lactoferrin: family of neutrophil granule glycoproteins that bind to an alveolar macrophage receptor. Proc. Natl. Acad. Sci. USA 79:6941-6945

53. Campbell, C. H., and D. D. Cunningham. 1987. Binding sites for elastase on cultured human fibroblasts that do not mediate internalization. J. Cell. Physiol. 130:142-149.

54. Kido, H., N. Fukusen, and N. Katanuma. 1985. Antibody and inhibitor of chymase inhibit histamine release in immunoglobulin Eactivated mast cells. Biochem. Int. 10:863-871.

55. Auberger, P., D. Mary, J. P. Breittmayer, C. Aussel, and M. Fehlmann. 1989. Chymotryptic-type protease inhibitors block the increase in $\mathrm{Ca}^{2+}$ and II-2 production in activated Jurkat T cells. J. Immunol. 142:1253-1259.

56. Mundy, D. I., and W. J. Strittmatter. 1985. Requirement for metalloendoprotease in exocytosis: evidence in mast cells and adrenal chromaffin cells. Cell. 40:645-656.

57. Suzuki, K., S. Imajoh, Y. Emori, H. Kawasaki, Y. Minami, and S. Ohno. 1987. Calcium-activated neutral protease and its endogenous inhibitor: activation at the cell membrane and biological function. FEBS (Fed. Eur. Biochem. Soc.) Lett. 220:271-277.

58. Schalkwijk, J., L. A. B. Joosten, W. B. van den Berg, and L. B. A. van de Putte. 1988. Degradation of cartilage proteoglycans by elastase is dependent on charge-mediated interactions. Rheumatol. Int. 8:27-33.

59. Heck, L. W., K. S. Rostand, F. A. Hunter, and A. Bhown. 1986. Isolation, characterization, and amino-terminal amino acid sequence analysis of human neutrophil cathepsin G from normal donors. Anal. Biochem. 158:217-227.

60. Senior, R. M., and E. J. Campbell. 1984. Cathepsin G in human mononuclear phagocytes: comparison between monocytes and U927 monocyte-like cells. J: Immunol. 132:2547-2551

61. Baugh, R. J., and J. Travis. 1976. Human leukocyte granule elastase: rapid isolation and characterization. Biochemistry. 15:836841 .

62. Heck, L. W., W. L. Darby, F. A. Hunter, A. Bhown, E. J. Miller, and J. C. Bennett. 1985. Isolation, characterization, and amino-terminal amino acid sequence analysis of human neutrophil elastase from normal donors. Anal. Biochem. 149:153-162.

63. De Water, R., L. N. A. Willems, G. N. P. van Muijen, C. Franken, J. A. M. Fransen, J. H. Dijkman, and J. A. Kramps. 1986. Ultrastructural localization of bronchial antileukoprotease in central and peripheral airways by a gold-labeling technique using monoclonal antibodies. Am. Rev. Respir. Dis. 133:882-890. 